Pretty Madern 



\section{Prettiy Madern}

BEAUTY, SEX, AND PLASTIC SURGERY IN BRAZIL

Alexander Edmonds

Duke University Press : : Durham and London :: 2010 
FOR MY PARENTS,

BARNEY EDMONDS AND

JULIE LOVE EDMONDS

(C) 2010 Duke University Press

All rights reserved

Printed in the United States

of America on acid-free paper @

Designed by Amy Ruth Buchanan

Typeset in Scala and Scala Sans

by Tseng Information Systems, Inc.

Library of Congress Catalogingin-Publication Data appear on the last printed page of this book. 
Only intellectuals like misery.

The paer prefer luxury.

- JOÃOSINHO TRINTA, CARNAVAL DESIGNER 